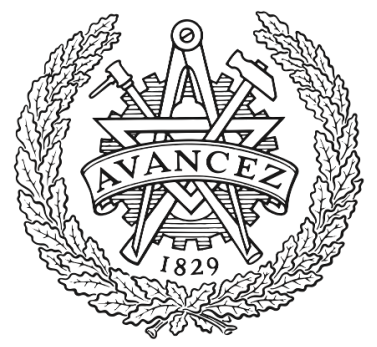

CHALMERS

UNIVERSITY OF TECHNOLOGY

\title{
Release of Terminal Alkynes via Tandem Photodeprotection and Decarboxylation of o -Nitrobenzyl Arylpropiolates in a Flow Microchannel
}

Downloaded from: https://research.chalmers.se, 2023-04-26 11:54 UTC

Citation for the original published paper (version of record):

Tebikachew, B., Börjesson, K., Kann, N. et al (2018). Release of Terminal Alkynes via Tandem Photodeprotection and Decarboxylation of o -Nitrobenzyl

Arylpropiolates in a Flow Microchannel Reactor. Bioconjugate Chemistry, 29(4): 1178-1185.

http://dx.doi.org/10.1021/acs.bioconjchem.7b00812

N.B. When citing this work, cite the original published paper. 


\title{
Release of Terminal Alkynes via Tandem Photodeprotection and Decarboxylation of o-Nitrobenzyl Arylpropiolates in a Flow Microchannel Reactor
}

\author{
Behabitu Ergette Tebikachew, ${ }^{\dagger}$ Karl Börjesson, ${ }^{\dagger}$ Nina Kann, ${ }^{\dagger}$ and Kasper Moth-Poulsen* ${ }^{\dagger} \uparrow$ \\ ${ }^{\dagger}$ Department of Chemistry and Chemical Engineering, Chalmers University of Technology, 41296 Gothenburg, Sweden \\ ${ }^{*}$ Department of Chemistry and Molecular Biology, University of Gothenburg, 41296 Gothenburg, Sweden
}

Supporting Information

ABSTRACT: Photocleavable protecting groups (PPGs) offer a complementary protection paradigm compared to traditional protection groups. Herein, an $o$-nitrobenzyl (NB) PPG was employed to protect a variety of arylpropiolic acids. Upon a cascade of light-triggered photodeprotection in a microchannel reactor (residence times of $100-500 \mathrm{~s}$ ), followed by $\mathrm{Cu}-$ catalyzed decarboxylation at $60{ }^{\circ} \mathrm{C}$, the NB-protected arylpropiolic acid afforded a terminal alkyne. This terminal alkyne was further reacted in situ with an azide via click chemistry to yield a 1,2,3-triazole in a one-pot reaction. Furthermore, the effect of different substituents (methyl, vinyl, allyl, and phenyl) at the benzylic position on the rate of photodeprotection was studied. The quantum yields of photolysis for the benzylic-substituted esters were determined to be as high as 0.45 compared to the unsubstituted ester with a 0.08 quantum yield of photolysis.

\section{INTRODUCTION}

Protecting groups are ubiquitous in modern synthetic organic chemistry as some functional groups are susceptible to undesired side reactions unless they are protected beforehand. A requirement for a good protecting group is the ability to be introduced and removed selectively and quantitatively. ${ }^{1}$ However, there is a lack of suitable groups that fulfill these requirements in all situations. In many cases, their deprotection requires harsh conditions and rarely proceeds quantitatively, limiting their range of applications. As a result, milder alternative methods for protection and deprotection have been investigated by many researchers. Among these, photocleavable protecting groups (PPGs) ${ }^{2-4}$ stand out because of their ability to use light as a traceless reagent to trigger the deprotection process. Besides providing orthogonal protection, ${ }^{5}$ PGGs also allow spatial and temporal control of the process. Hence, they are very attractive for various applications such as controlled drug delivery, ${ }^{6}$ total synthesis, ${ }^{7}$ photoresponsive polymers, ${ }^{8}$ and surface modification processes such as surface patterning and photolithograhy. ${ }^{9-11}$

Despite the abundance of various PPGs in the literature, ${ }^{2,12-14} o$-nitrobenzyl (NB) has been among the most commonly used. This protecting group was first used by Barltrop et al. to protect various carboxylic acids. ${ }^{15}$ Kaplan et al. also used it to protect and release biologically relevant molecules such as adenosine triphosphate (ATP). ${ }^{16}$ The application range has been further extended to allow use under physiological conditions. ${ }^{2}$

Terminal alkynes have a prime importance in various chemical transformations, such as Glaser coupling, ${ }^{17}$ the Sonogashira-Hagihara protocol, ${ }^{18}$ and click chemistry. ${ }^{19-21}$ In addition, terminal alkynes are widely used as building blocks in various molecular transformations that are pertinent for biological $^{22,23}$ as well as molecular electronics applications. ${ }^{24}$ However, some terminal alkynes are prone to oxidation and are inconvenient to handle because of their high volatility. ${ }^{25}$ In addition, during palladium-catalyzed cross coupling reactions between aryl halides and terminal alkynes, dimerization of alkynes often occurs as a side reaction, ${ }^{17}$ reducing the yield of the cross coupling reaction. Consequently, an excess of alkyne has to be used. To alleviate this use of an additional alkyne, an elegant method has been reported by Kolarovic et al., ${ }^{26}$ using alkynoic acids in a stoichiometric amount as a source of terminal alkyne via in situ decarboxylation. The generated terminal alkyne was then further reacted with an azide to yield 1,2,3-triazoles in a one-pot process. However, the carboxylic acid functionality may present compatibility issues and limitations in terms of the reaction conditions used. Hence,

Received: December 20, 2017

Revised: February 19, 2018

Published: February 21, 2018 
protecting the carboxylic acid moiety is imperative, for instance, with a PPG.

Gschneidtner et al. ${ }^{27}$ have demonstrated the first example of using PPGs to protect terminal alkynes via PPG-protected propargylic alcohols. A series of tertiary propargylic ethers containing an NB group were prepared. Upon photoirradiation at $365 \mathrm{~nm}$ under alkaline reflux conditions, various terminal alkynes were released in satisfactory yields. However, the long reaction times and strong basic conditions employed in this method may limit its application. Kakiuchi and co-workers have also presented a novel thiochromone-based photocleavable group, employing thiochromone $S, S$-dioxides to protect various types of amines, alcohols, and carboxylic acids. ${ }^{28}$ They reported an almost quantitative photodeprotection under ultraviolet (UV) light. More recently, the same group also applied their new PPG in the protection of propargylic alcohols in the form of propargylic ethers. ${ }^{29}$ However, their PPG requires multistep synthetic procedures, and more importantly, the purpose was not for releasing terminal alkynes in this case.

To the best of our knowledge, photocleavable protection of arylpropiolic acid [1a (Scheme 1a)] for the release of terminal alkynes has not been reported hitherto.

Scheme 1. Substituted (a) Arylpropiolic Acids and (b) oNitrobenzyl Alcohols Used as Precursors in This Study

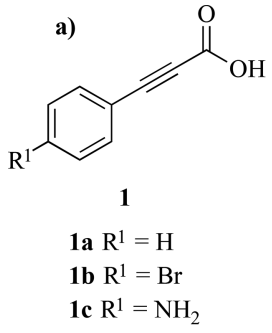

$$
\begin{aligned}
& \text { b) } \\
& \text { (1) } \\
& \text { 2a } \mathrm{R}^{2}=\mathrm{H} \\
& \text { 2b R } \mathrm{R}^{2}=\text { methyl } \\
& \text { 2c } \mathrm{R}^{2}=\text { vinyl } \\
& \text { 2d } \mathrm{R}^{2}=\text { allyl } \\
& \text { 2e } \mathrm{R}^{2}=\text { phenyl }
\end{aligned}
$$

Here, we, for the first time, employ NB PPGs for the protection of arylpropiolic acids and demonstrate the lighttriggered release of terminal alkynes "on demand" at $60{ }^{\circ} \mathrm{C}$. This makes our approach attractive for future surface modification applications, for which mild conditions are required. Moreover, to investigate the role of benzylic substitution on the rate of deprotection, various substituents, i.e., methyl, vinyl, allyl, and phenyl, were introduced at the benzylic position (Scheme $1 \mathrm{~b}$ ), and the results from these studies are disclosed herein.

\section{RESULTS AND DISCUSSION}

Synthesis of Starting Materials. The synthesis of carboxylic acid-protected terminal alkynes $\mathbf{1 a - c}$ (Scheme 1a) was achieved in satisfactory yields (65-70\%) using a Sonogashira reaction between the corresponding aryl iodides and propiolic acid, using a modified literature method. ${ }^{30}$ While, $o$-nitrobenzyl alcohol was obtained from a commercial source, its benzyl-substituted analogues $\mathbf{2} \mathbf{b}-\mathbf{e}$ (Scheme $1 \mathbf{b}$ ) were prepared via the reaction of $o$-nitrobenzaldehyde with the corresponding Grignard reagents. With both precursors in hand, the esterification reaction was then pursued to couple the two moieties. This was achieved via a microwave-assisted Steglich esterification ${ }^{31}$ at $40{ }^{\circ} \mathrm{C}$, furnishing $3 \mathrm{a}-\mathrm{e}$ in good yields in a relatively short reaction time (30 $\mathrm{min})$ as compared to that under conventional conditions ( $>3 \mathrm{~h}$ ) (Scheme 2). The products were easily purified by flash chromatography, without any complications caused by the side product dicyclohexylurea.

Characterization. All products were fully characterized by ${ }^{1} \mathrm{H}$ NMR, ${ }^{13} \mathrm{C}$ NMR, ATR-IR, and LC-MS. The UV-visible absorption spectra of acetonitrile solutions of $3 \mathbf{a}-\mathbf{e}$ as well as 1a are shown in Figure 1. Despite the benzylic substitution, the esters have very similar absorption spectra as well as molar extinction coefficients $(\varepsilon)$, with absorption maxima around 260 $\mathrm{nm}$. However, relative to the reference acid 1a, they all display a hyperchromic as well as bathochromic shift.

To investigate the photodeprotection process, acetonitrile solutions of $3 \mathbf{a}-\mathbf{e}$ were prepared. Photoirradiation was performed with a hand-held UV lamp operated at $254 \mathrm{~nm}$. The photoirradiation experiments demonstrate that NBprotected esters $(3 \mathbf{a}-\mathbf{e})$ have been photolyzed little as compared to 1a, while the latter has been photolyzed significantly during the photoirradation experiment time. This is expected as decarboxylation of carboxylic moieties upon nearUV irradiation has been demonstrated in other studies,

Scheme 2. Microwave-Assisted Steglich Esterification Reaction and the Corresponding PPG-Protected Esters (3a-e)

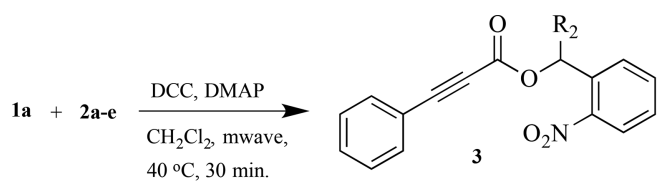<smiles>O=C(C#Cc1ccccc1)OCc1ccccc1[N+](=O)[O-]</smiles><smiles>CC(OC(=O)C#Cc1ccccc1)c1ccccc1[N+](=O)[O-]</smiles><smiles>C=CC(OC(=O)C#Cc1ccccc1)c1ccccc1[N+](=O)[O-]</smiles><smiles>C=CCC(OC(=O)C#Cc1ccccc1)c1ccccc1[N+](=O)[O-]</smiles><smiles>O=C(C#Cc1ccccc1)OC(c1ccccc1)c1ccccc1[N+](=O)[O-]</smiles> 


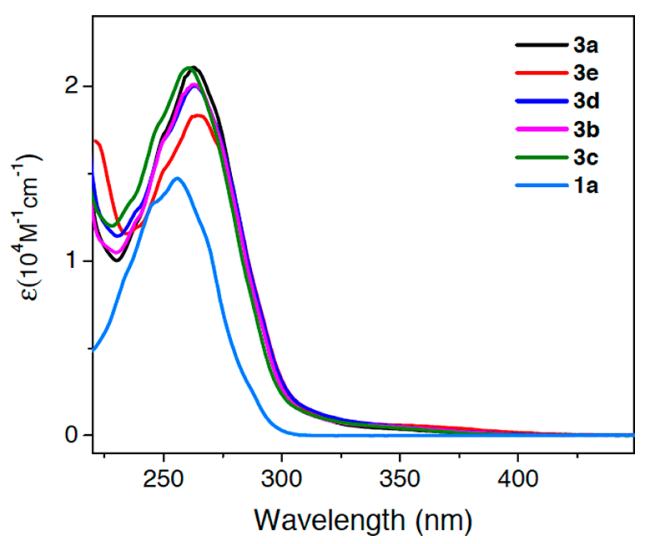

Figure 1. UV-visible absorption spectra of $1 \mathbf{a}$ and $3 \mathbf{a}-\mathbf{e}$ in acetonitrile.

highlighting the importance of protecting the carboxylic acid moiety if one wishes to use photochemistry in the UV region. ${ }^{32}$ The implication of these results is that once the NB group is photoremoved, the decarboxylation process is relatively efficient. Hence, the total photodeprotection-decarboxylation process to generate the terminal alkyne is governed by the first photodeprotection process.

In addition, the thermal stability of $1 \mathbf{a}$ and $3 \mathbf{a}-\mathbf{e}$ was also tested by thermogravimetric studies. At $210{ }^{\circ} \mathrm{C}$, a $>90$ wt \% loss was observed for 1a as compared to a $<5$ wt \% loss for the esters. This result indicates that NB-protected esters $(3 \mathbf{a}-\mathbf{e})$ are thermally more stable than $1 \mathrm{a}$, showing the robustness of our NB esters (see Figure S4).

It is known that the photoremoval of NBs at high concentrations requires either high-intensity light ${ }^{33}$ or a large surface area to be efficient. ${ }^{34,35}$ Henceforth, a quartz microchannel flow reactor (62.5 $\mu \mathrm{L}$ capacity) was utilized to investigate the photodeprotection. The advantage of using microchannel flow reactors is that over time, the whole solution will be under uniform irradiation, leading to efficient photoreaction. Also, by controlling the flow rate and reactor volume, one can precisely tune the photoirradiation time as desired. ${ }^{36}$

Consequently, a $5 \mathrm{mM} \mathrm{CDCl}$ solution of $3 \mathbf{b}$ was injected through the reactor chip at rates of $2.0,1.2$, and $0.4 \mathrm{~mL} / \mathrm{h}$, with residence times of approximately 100, 167, and $500 \mathrm{~s}$, respectively, in the microchannel. The irradiated samples were then studied by ${ }^{1} \mathrm{H}$ NMR. The experiment led to 41 , 74 , and $100 \%$ photodeprotection for the 100, 167, and $500 \mathrm{~s}$ UV irradiations, respectively, as shown in the ${ }^{1} \mathrm{H}$ NMR spectra in Figure 2. Moreover, the areas of the proton peaks from the proton next to the nitro group (c) and the benzylic proton (b) on the NB as well as the methyl doublet (a) have decreased (Figure 2, spectrum 1), while a new aromatic peak $\left(c^{\prime}\right)$ at 7.0 ppm and a methyl peak $\left(a^{\prime}\right)$ at $2.7 \mathrm{ppm}$ from one of the photoproducts, nitrosoacetophenone, have also emerged (Figure 2, spectrum 2). The second peak at $2.6 \mathrm{ppm}$ labeled $\mathrm{d}$ is most likely due to the methyl peaks of the dimer formed from nitrosoacetophenone. ${ }^{37}$ However, because one of the photoproducts, phenylpropiolic acid, is a carboxylic acid, ${ }^{38}$ its protons were not observed, due to proton exchange with the NMR solvent.

To investigate the effect of substitution at the benzylic position, the absorption values of $3 \mathbf{a}-\mathbf{e}$ at $325 \mathrm{~nm}$ were plotted versus time (Figure 3 ). The temporal evolution of the

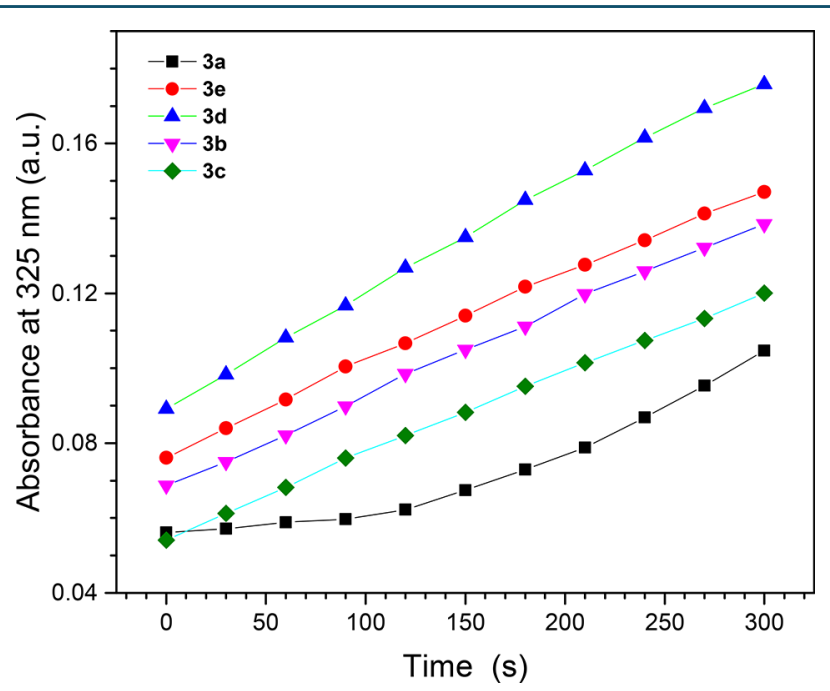

Figure 3. Evolution of the absorption of compounds 1a-e at $325 \mathrm{~nm}$ vs time during photolysis.

absorbance for the unsubstituted ester (3a) is the least pronounced as compared to those of the compounds

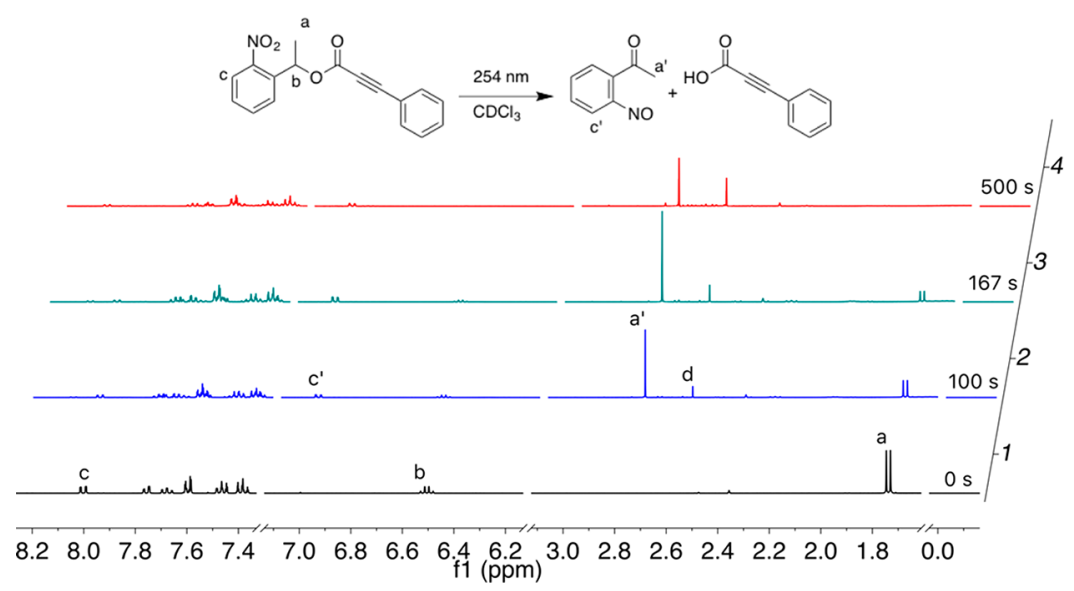

Figure 2. ${ }^{1} \mathrm{H}$ NMR spectra for the photodeprotection of $3 \mathbf{b}$ with a $254 \mathrm{~nm}$ UV lamp at a different exposure times. Spectrum 1 was recorded prior to UV irradiation, while spectra 2-4 represent photodeprotection at residence times inside the microchannel of 100, 167, and 500 s, respectively, corresponding to flow rates of $2,1.2$, and $0.4 \mathrm{~mL} / \mathrm{h}$, respectively. Furthermore, new peaks $\mathrm{a}^{\prime}, \mathrm{c}^{\prime}$, and d emerge, while peaks a-c disappear gradually. 


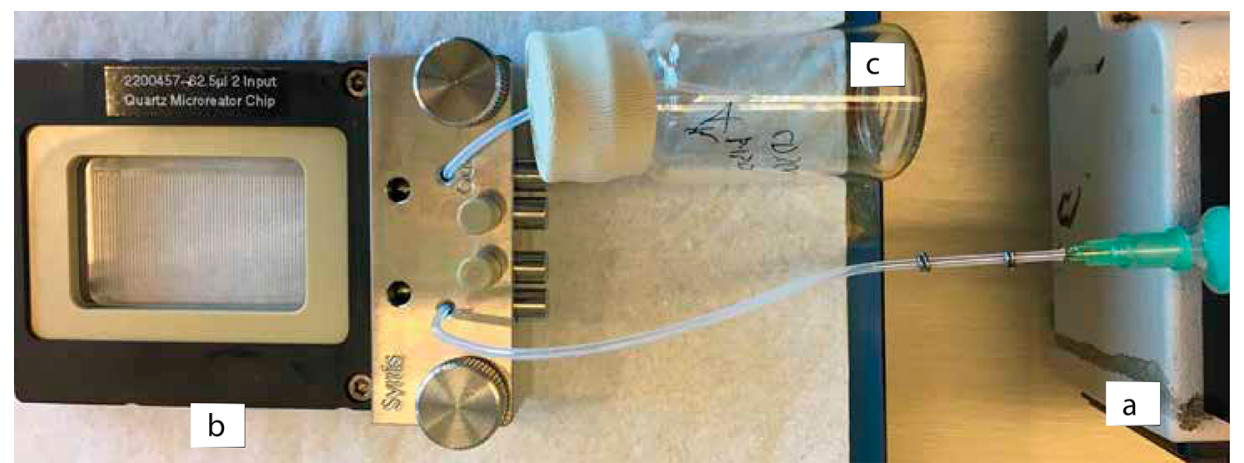

Figure 4. Picture of the chip-based microreactor setup. (a) Syringe pump for injecting the solutions into the microfluidic chamber. (b) Quartz microreactor $(62.5 \mu \mathrm{L})$ in which the PPG-protected esters are irradiated with a $254 \mathrm{~nm}$ UV lamp. (c) Collection vial that contains the reagents for the $\mathrm{CuAAC}$ reaction.

Scheme 3. Tandem Reactions Involving Photodeprotection and Decarboxylation, Followed by CuAAC at $60{ }^{\circ} \mathrm{C}$ for 15 min in $\mathrm{CH}_{2} \mathrm{Cl}_{2}$

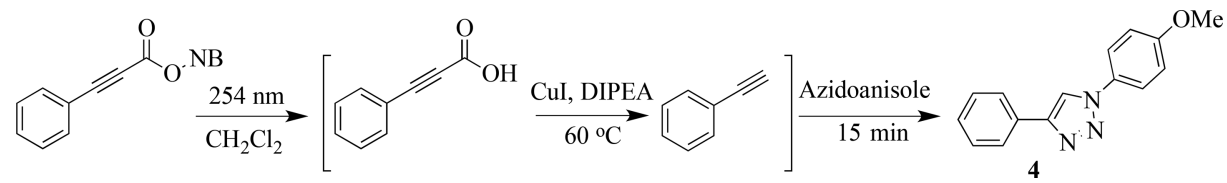

substituted at the benzylic position (Figure 3). Furthermore, the line for $3 \mathbf{a}$ is not straight. This may be explained by undesired side reactions of the aldehyde byproduct. In the four remaining molecules, as a result of the benzylic substitution, the byproducts are less reactive ketones.

The faster rate for the allyl-substituted molecule $\mathbf{3 d}$ can also be rationalized in terms of the favorable proximity of the nitroso and allyl moiety for the nitroso-ene reaction. ${ }^{39}$ This interaction traps the reactive nitroso moiety from undesired side reactions, as demonstrated in the past by Pirrung et al., using a diene in this case.

Furthermore, assuming clean photoreaction at low photoconversion, the quantum yields of photolysis $\left(Q_{p}\right)$ for $3 \mathbf{a}-\mathbf{e}$ were determined by UV-visible $(\mathrm{a})$ spectroscopy $\left(\lambda_{\text {photolysis }}=\right.$ $\left.254 \mathrm{~nm} ; \lambda_{\text {obs }}=325 \mathrm{~nm}\right)$ to be $0.08,0.41,0.41,0.44$, and 0.45 , respectively (for details, see Figure $\mathrm{S} 1$ ). This result underscores a significant improvement in $Q_{p}$ for the benzylic substituted esters $(\mathbf{3 b}-\mathbf{e})$ in comparison to that of the unsubstituted ester (3a).

To further demonstrate the release of the terminal alkyne from the NB-protected arylpropiolates, a tandem photodeprotection-decarboxylation reaction followed by a coppercatalyzed alkyne-azide cycloaddition (CuAAC) "click" reaction was performed; $1 \mathrm{mM}$ solutions of NB-protected phenylpropiolic acids $3 \mathbf{a}-\mathbf{e}$ were injected into a flow microchannel reactor chip $(62.5 \mu \mathrm{L})$ while being irradiated with a $254 \mathrm{~nm} \mathrm{UV}$ lamp to trigger the photodeprotection of NB (Figure 4).

Then, the collected solution was transferred directly to a vial containing a copper salt $\left[\mathrm{CuI}\right.$ or $\left.\mathrm{Cu}(\mathrm{acac})_{2}\right]$, Hünig's base, and acetic acid, followed by the addition of azidoanisole at $60{ }^{\circ} \mathrm{C}$, and reacted for $15 \mathrm{~min}$ (Scheme 3). LC-MS analysis as well as ${ }^{1} \mathrm{H}$ NMR studies indicated the formation of the desired cycloaddition product, [1-(4-methoxyphenyl)-4-phenyl]-1H1,2,3-triazole (4), in the crude reaction mixture (see the Supporting Information for ${ }^{1} \mathrm{H}$ NMR data). The cascade reaction proceeded in modest yields for most of the substrates at a flow rate of $2 \mathrm{~mL} / \mathrm{h}$ (Table 1, entries 2, 5, 6, and 10) using $\mathrm{CuI}$ as the catalyst (Table 1 ). At this flow rate, the yield for the
Table 1. Optimization and Demonstration of the Scope of the One-Pot Photodeprotection-Decarboxylation-CuAAC Reaction

\begin{tabular}{|c|c|c|c|c|c|}
\hline entry & substrate & $\begin{array}{l}\text { residence } \\
\text { time }(\mathrm{s})\end{array}$ & solvent & catalyst & $\begin{array}{l}\text { yield } \\
(\%)^{a}\end{array}$ \\
\hline 1 & $3 a$ & 100 & $\mathrm{CH}_{2} \mathrm{Cl}_{2}$ & $\mathrm{CuI}$ & 5 \\
\hline 2 & $3 b$ & 100 & $\mathrm{CH}_{2} \mathrm{Cl}_{2}$ & $\mathrm{CuI}$ & 21 \\
\hline 3 & $3 b$ & 167 & $\mathrm{CH}_{2} \mathrm{Cl}_{2}$ & $\mathrm{CuI}$ & 27 \\
\hline 4 & $3 b$ & 500 & $\mathrm{CH}_{2} \mathrm{Cl}_{2}$ & $\mathrm{CuI}$ & 41 \\
\hline 5 & $3 c$ & 100 & $\mathrm{CH}_{2} \mathrm{Cl}_{2}$ & $\mathrm{CuI}$ & 19 \\
\hline 6 & $3 d$ & 100 & $\mathrm{CH}_{2} \mathrm{Cl}_{2}$ & $\mathrm{CuI}$ & 17 \\
\hline 7 & $3 d$ & 100 & $\mathrm{CH}_{2} \mathrm{Cl}_{2}$ & $\mathrm{Cu}(\mathrm{acac})_{2}$ & $23^{b}$ \\
\hline 8 & $3 d$ & 500 & $\mathrm{CH}_{2} \mathrm{Cl}_{2}$ & $\mathrm{CuI}$ & 28 \\
\hline 9 & $3 e$ & 100 & $\mathrm{CH}_{2} \mathrm{Cl}_{2}$ & $\mathrm{Cu}(\mathrm{acac})_{2}$ & $20^{b}$ \\
\hline 10 & $3 e$ & 100 & $\mathrm{CH}_{2} \mathrm{Cl}_{2}$ & $\mathrm{CuI}$ & $28^{b}$ \\
\hline 11 & $3 e$ & 100 & $\mathrm{MeCN}$ & $\mathrm{CuI}$ & $\begin{array}{l}\text { no } \\
\text { reaction }\end{array}$ \\
\hline 12 & 1a & $\begin{array}{l}\text { not } \\
\text { available }\end{array}$ & $\mathrm{CH}_{2} \mathrm{Cl}_{2}$ & $\mathrm{CuI}$ & 45 \\
\hline 13 & ethynylbenzene & $\begin{array}{l}\text { not } \\
\text { available }\end{array}$ & $\mathrm{CH}_{2} \mathrm{Cl}_{2}$ & $\mathrm{CuI}$ & 54 \\
\hline
\end{tabular}

${ }^{a}$ Overall yields for the three step-reaction shown in Scheme 3 determined by ${ }^{1} \mathrm{H}$ NMR, using methyl 3,5-dinitrobenzoate as the internal standard. ${ }^{b}$ Yields are given as an average from two experiments.

unsubstituted ester 3a (entry 1) is rather low. At lower flow rates, the yields improve accordingly (entries 3,4 , and 8 ). In particular, for $3 \mathbf{b}$ (entry 4) at a flow rate of $0.4 \mathrm{~mL} / \mathrm{h}(500 \mathrm{~s}$ residence time), the yield was significantly improved to $41 \%$ after the three-step cascade photodeprotection-decarboxylation-CuAAC reaction, becoming comparable to that of the control reaction of $\mathbf{1 a}$ (entry 12).

The versatility of our substrate has also been tested with a $\mathrm{Cu}(\mathrm{acac})_{2}$-catalyzed decarboxylation-CuAAC reaction (entries 7 and 9). The desired triazole click product was obtained with this method, as well, with yields comparable to those of the CuI method at the corresponding flow rates. When acetonitrile was used as a solvent instead of dichloromethane, the click reaction 
did not yield the desired product (entry 11). This could be explained by the inefficiency of the CuAAC click reaction in dilute solutions. ${ }^{40}$ One reason that the click reaction works in dichloromethane is that the solvent evaporates partially at the temperature employed $\left(60^{\circ} \mathrm{C}\right)$, leading to a more concentrated solution, which facilitates the reaction.

Hence, besides controlling the residence time through the microchannel reactor, we found in our study that choosing the right type of solvent is important for the entire photodeprotection-decarboxylation-click reaction cascade process to proceed efficiently.

\section{CONCLUSION}

In summary, a series of $o$-nitrobenzyl phenylpropiolates was synthesized for investigation of light-triggered release of terminal alkynes. The photodeprotection at $254 \mathrm{~nm}$ was followed by ${ }^{1} \mathrm{H} \mathrm{NMR}$, indicating the release of phenylpropiolic acid, which further underwent copper-catalyzed decarboxylative cleavage in situ to yield a terminal alkyne, phenylacetylene. In addition, the benzylic position of the NB group was modified with methyl, vinyl, allyl, and phenyl moieties. The quantum yields of photolysis for the benzylic substituted esters $(3 \mathbf{b}-\mathbf{e})$ were determined to be as high as 0.45 . As a proof of concept, solutions of the alkyne esters were pumped via a flow microchannel reactor while being irradiated with a $254 \mathrm{~nm}$ UV lamp to increase the efficiency of photodeprotection. At a rate of $0.4 \mathrm{~mL} / \mathrm{h}$ (500 s residence time), quantitative photodeprotection of the NB group was found. A tandem photodeprotection-decarboxylation reaction, followed by $\mathrm{Cu}$ catalyzed click reaction on the liberated alkyne in situ with azidoanisole, afforded the anticipated 1,4-disubstituted 1,2,3triazole product at $60{ }^{\circ} \mathrm{C}$. This way of releasing terminal alkynes could find potential applications in organic synthesis as well as in surface modification by incorporation of thiolfunctionalized substrates.

\section{EXPERIMENTAL SECTION}

Materials and Methods. Starting materials were purchased from commercial suppliers and used without further purification unless stated otherwise. All dry solvents were obtained using an mBraun MB SPS- 800 solvent purification system. Dichloromethane was dried over $3 \AA$ molecular sieves. All reactions were performed under nitrogen media in a fume hood. The progress of the reaction was followed by thin layer chromatography (TLC) on precoated aluminum plates, Merck Silica gel $60 \mathrm{~F}_{254}$, and the spots were visualized with the aid of a hand-held UV lamp (254 and $365 \mathrm{~nm}$ ). Phenylpropiolic acid was prepared starting from iodophenol and propiolic acid via a Sonogashira reaction. Purification of the compounds was performed using automated flash chromatography (Biotage Isolera Spektra One). ${ }^{1} \mathrm{H}$ and ${ }^{13} \mathrm{C}$ NMR spectra were recorded by an automated Agilent (Varian) MR $400(400 \mathrm{MHz})$ spectrometer equipped with a "One-probe". The chemical shifts are given in parts per million downfield from tetramethylsilane using the residual solvent signal as a reference. IR spectra were acquired on a PerkinElmer Frontier FTIR spectrometer equipped with an ATR device. The data were processed with Spectrum software. LC-MS (ESI) data were acquired on a PerkinElmer PE SCIEX API 150 EX instrument with a Turbolon spray ion source equipped with a Gemini $5 \mathrm{~mm}$ RP-C18 $110 \AA$ column, using a $\mathrm{H}_{2} \mathrm{O} / \mathrm{MeCN}$ gradient (95:5 to
5:95) with $0.1 \% \mathrm{HCO}_{2} \mathrm{H}$. UV-visible spectra were recorded on a PerkinElmer Lambda 900 UV/vis/NIR spectrometer.

Synthetic Procedures. General Procedure for the Preparation of Various Arylpropiolic Acids via Sonogashira Reaction. To a two-neck round-bottom flask provided with a stirring bar containing a mixture of aryl iodide $(10 \mathrm{mmol})$, $\mathrm{Pd}\left(\mathrm{PPh}_{3}\right)_{2} \mathrm{Cl}_{2}(2 \mathrm{~mol} \%), \mathrm{CuI}(4 \mathrm{~mol} \%)$, and DMF $(15 \mathrm{~mL})$ was added propiolic acid $(12 \mathrm{mmol})$ followed by the dropwise addition of diisopropylamine under nitrogen. The mixture was stirred for $5 \mathrm{~h}$. At this point, the content was diluted with ethyl acetate and passed through a short plug of silica gel. The filtrate was washed with a cold aqueous $\mathrm{KOH}$ solution $(1 \mathrm{M}, 100 \mathrm{~mL}$ ) to extract the product, which was subsequently acidified with a cold $\mathrm{HCl}$ solution $(1 \mathrm{M})$ kept in an ice bath. Then, the organic phase was extracted with dichloromethane and washed with water and brine consecutively in a separatory funnel; the organic phase was separated and dried over anhydrous $\mathrm{MgSO}_{4}$ and filtered, and the solvent was removed using a rotary evaporator to yield the desired product.

Phenylpropiolic Acid (1a). Phenyl iodide (2.04 g, $10 \mathrm{mmol}$ ) was reacted with propiolic acid $(0.79 \mathrm{~mL}, 12 \mathrm{mmol})$, $\mathrm{Pd}\left(\mathrm{PPh}_{3}\right)_{2} \mathrm{Cl}_{2}(2 \mathrm{~mol} \%), \mathrm{CuI}(4 \mathrm{~mol} \%)$, and diisopropylamine $(15 \mathrm{~mL})$ as described in the general procedure to afford the product as an off-white solid (0.95 g, 65\%). NMR data were consistent with literature data: ${ }^{30}{ }^{1} \mathrm{H}$ NMR $\left(400 \mathrm{MHz}, \mathrm{CDCl}_{3}\right)$ $\delta 7.57(\mathrm{~m}, 2 \mathrm{H}), 7.42(\mathrm{~m}, 1 \mathrm{H}), 7.35(\mathrm{~m}, 2 \mathrm{H}) ;{ }^{13} \mathrm{C}$ NMR $(101$ $\left.\mathrm{MHz}, \mathrm{CDCl}_{3}\right) \delta 156.2$, 133.1, 130.6, 128.6, 120.0, 86.3, 81.3.

p-Bromophenylpropiolic Acid (1b). p-Bromophenyl iodide $(2.83 \mathrm{~g}, 10 \mathrm{mmol})$ was reacted with propiolic acid $(0.79 \mathrm{~mL}, 12$ $\mathrm{mmol}), \mathrm{Pd}\left(\mathrm{PPh}_{3}\right)_{2} \mathrm{Cl}_{2}$ (2 mol \%), CuI (4 mol \%), and diisopropylamine $(15 \mathrm{~mL})$ as described in the general procedure to afford the product as a gray solid (1.53 g, 68\%). NMR data were consistent with literature data: ${ }^{41}{ }^{1} \mathrm{H}$ NMR $\left(400 \mathrm{MHz} \mathrm{CDCl}_{3}\right) \delta 7.52(\mathrm{~m}, 2 \mathrm{H}), 7.44(\mathrm{~m}, 2 \mathrm{H}) ;{ }^{13} \mathrm{C} \mathrm{NMR}$ $\left(101 \mathrm{MHz}, \mathrm{CDCl}_{3}\right) \delta 155.9,134.5,132.1,125.5,118.8,85.4$, 82.0.

p-Aminophenylpropiolic Acid (1c). Boc-p-aminophenyl iodide $(1.5 \mathrm{~g}$, $4.9 \mathrm{mmol})$ was reacted with propiolic acid (0.4 $\mathrm{mL}, 6 \mathrm{mmol}), \mathrm{Pd}\left(\mathrm{PPh}_{3}\right)_{2} \mathrm{Cl}_{2}(2 \mathrm{~mol} \%)$, CuI (4 mol \%), and diisopropylamine $(10 \mathrm{~mL})$ as described in the general procedure to afford the product as an off-white solid $(0.9 \mathrm{~g}$, 70\%): ${ }^{1} \mathrm{H}$ NMR (400 MHz, DMSO) $\delta 7.66(\mathrm{~m}, 2 \mathrm{H}), 7.55(\mathrm{~m}$, $2 \mathrm{H}), 1.48(\mathrm{~s}, 9 \mathrm{H}) ;{ }^{13} \mathrm{C}$ NMR (101 MHz, DMSO) $\delta$ 164.4, 163.1, 152.9, 144.4, 128.5, 123.1, 96.5, 90.9, 90.04.

General Procedure for the Synthesis of o-Nitrobenzyl Alcohols $(2 \boldsymbol{e}-\boldsymbol{h})$. To a stirring solution of $o$-nitrobenzaldehyde $(33 \mathrm{mmol})$ in THF $(70 \mathrm{~mL})$ at $-78{ }^{\circ} \mathrm{C}$ in an acetone/liquid nitrogen bath was added dropwise a Grignard reagent (35 $\mathrm{mmol}$ ). The color of the solution changed from yellow to brown, and the mixture was allowed to react for $1 \mathrm{~h}$. Then, the solution was warmed to room temperature and left to stir overnight. To this solution was added diethyl ether $(50 \mathrm{~mL})$, and the reaction was quenched with a saturated ammonium chloride solution. Any precipitated solids were filtered off, and the solvents were removed using rotary evaporation. The crude product was re-dissolved in dichloromethane $(30 \mathrm{~mL})$ and washed with distilled water and brine in a separatory funnel. The organic phase was then collected, dried over anhydrous $\mathrm{MgSO}_{4}$, and filtered. The solvent was removed using a rotary evaporator to afford a crude product, which was subsequently purified by automated flash chromatography with a gradient of 0 to $10 \%$ ethyl acetate in hexane. 
1-(2-Nitrophenyl)ethan-1-ol (2b). Methylmagnesium bromide ( $3 \mathrm{M}$ in diethyl ether, $11.7 \mathrm{~mL}, 35 \mathrm{mmol}$ ) was used, affording $2 \mathrm{e}$ as a yellowish oil (1.52 g, 28\%). NMR data were consistent with literature data: ${ }^{42}{ }^{1} \mathrm{H}$ NMR $\left(400 \mathrm{MHz}, \mathrm{CDCl}_{3}\right)$ $\delta 7.84(\mathrm{dd}, 1 \mathrm{H}), 7.65$ (tdd $J=7.9,1.4,0.5 \mathrm{~Hz}, 1 \mathrm{H}), 7.42$ (ddd, $J=8.1,7.3,1.5 \mathrm{~Hz}, 1 \mathrm{H}), 5.41(\mathrm{q}, J=6.4 \mathrm{~Hz}, 1 \mathrm{H}), 1.57$ (d, $J=$ $6.4 \mathrm{~Hz}, 3 \mathrm{H}) ;{ }^{13} \mathrm{C} \mathrm{NMR}(101 \mathrm{MHz}, \mathrm{CDCl} 3) \delta 148.0,141.0$, 133.7, 128.2, 127.7, 124.4, 65.7, 24.3.

1-(2-Nitrophenyl)prop-2-en-1-ol (2c). Vinylmagnesium bromide ( $1 \mathrm{M}$ in THF, $35 \mathrm{~mL}, 35 \mathrm{mmol}$ ) was used, affording $\mathbf{2} \mathbf{f}$ as a yellowish oil $(3.86 \mathrm{~g}, 65 \%)$. NMR data were consistent with literature data: ${ }^{43}{ }^{1} \mathrm{H}$ NMR $\left(400 \mathrm{MHz}, \mathrm{CDCl}_{3}\right) \delta 7.91(\mathrm{~m}, 1 \mathrm{H})$, $7.76(\mathrm{~m}, 1 \mathrm{H}), 7.64(\mathrm{tdd}, J=7.4,7.4,1.3,0.5 \mathrm{~Hz}, 1 \mathrm{H}), 7.44(\mathrm{~m}$, $1 \mathrm{H}), 6.07$ (dddd, $J=17.2,10.5,5.2,0.8 \mathrm{~Hz}, 1 \mathrm{H}), 5.79(\mathrm{dt}, J=$ 5.4, $1.4,1.4 \mathrm{~Hz}, 1 \mathrm{H}), 5.41(\mathrm{dtd}, J=17.2,1.4,1.3,0.8 \mathrm{~Hz}, 1 \mathrm{H})$, $5.26(\mathrm{dtd}, J=10.5,1.3,1.3,0.8 \mathrm{~Hz}, 1 \mathrm{H}), 2.63$ (bs, $1 \mathrm{H}) ;{ }^{13} \mathrm{C}$ NMR $\left(101 \mathrm{MHz}, \mathrm{CDCl}_{3}\right) \delta 148.1,137.8,137.3,133.4,128.7$, 128.3, 124.4, 116.0, 69.8.

1-(2-Nitrophenyl)but-3-en-1-ol (2d). Allylmagnesium bromide ( $1 \mathrm{M}$ in THF, $35 \mathrm{~mL}, 35 \mathrm{mmol}$ ) was used, affording $2 \mathrm{~g}$ as a colorless oil $(0.97 \mathrm{~g}, 16 \%)$. NMR data were consistent with literature data: ${ }^{44} \mathrm{H}$ NMR $\left(400 \mathrm{MHz}, \mathrm{CDCl}_{3}\right) \delta 7.92(\mathrm{~m}, 1 \mathrm{H})$, $7.82(\mathrm{~m}, 1 \mathrm{H}), 7.65(\mathrm{~m}, 1 \mathrm{H}), 7.42(\mathrm{~m}, 1 \mathrm{H}), 5.89(\mathrm{~m}, 1 \mathrm{H}), 5.31$ (dd, $J=8.4,3.7 \mathrm{~Hz}, 1 \mathrm{H}), 5.21(\mathrm{~m}, 1 \mathrm{H}), 5.18(\mathrm{t}, J=1.2,1.2 \mathrm{~Hz}$, $1 \mathrm{H}), 2.70(\mathrm{~m}, 1 \mathrm{H}), 2.42(\mathrm{~m}, 2 \mathrm{H}) ;{ }^{13} \mathrm{C}$ NMR (101 MHz, $\left.\mathrm{CDCl}_{3}\right) \delta 147.8,139.2,133.9,133.4,128.1,128.1,124.4,119.1$, 68.4, 42.8 .

(2-Nitrophenyl)(phenyl)methanol (2e). Phenylmagnesium bromide [freshly prepared from phenyl bromide $(3.5 \mathrm{~mL}, 35$ $\mathrm{mmol}$ ) and magnesium turnings (0.9 g, $35 \mathrm{mmol})$ in THF] was used, affording $2 \mathrm{e}$ as an orange oil $(5.47 \mathrm{~g}, 72 \%)$. NMR data were consistent with literature data: ${ }^{45}{ }^{1} \mathrm{H}$ NMR $(400 \mathrm{MHz}$, $\left.\mathrm{CDCl}_{3}\right) \delta 7.91(\mathrm{dd}, J=8.2,1.3 \mathrm{~Hz}, 1 \mathrm{H}), 7.72(\mathrm{dd}, J=7.9,1.5$ $\mathrm{Hz}, 1 \mathrm{H}), 7.61(\mathrm{td}, J=7.8,7.7,1.3 \mathrm{~Hz}, 1 \mathrm{H}), 7.43(\mathrm{~m}, 1 \mathrm{H}), 7.32$ $(\mathrm{m}, 6 \mathrm{H}), 6.40(\mathrm{~d}, J=2.5 \mathrm{~Hz}, 1 \mathrm{H}), 2.77(\mathrm{~s}, 1 \mathrm{H}) ;{ }^{13} \mathrm{C}$ NMR $(101$ $\left.\mathrm{MHz}, \mathrm{CDCl}_{3}\right) \delta 148.5,141.6,138.6,133.5,129.5,128.7,128.6$, 128.2, 127.0, 124.8, 71.6.

General Procedure for the Microwave-Assisted Esterification Reaction $(\mathbf{1 d}-\boldsymbol{h})$. To a stirring solution of phenylpropiolic acid ( $2 \mathrm{mmol}, 0.32 \mathrm{~g})$ in dry $\mathrm{CH}_{2} \mathrm{Cl}_{2}$ cooled in an ice bath were added the alcohol $(2 \mathrm{mmol}), \mathrm{DCC}(2 \mathrm{mmol})$, and DMAP (10 $\mathrm{mol} \%)$, in that order. The microwave vial was sealed, and the mixture was heated in a microwave reactor at $40{ }^{\circ} \mathrm{C}$ for $30 \mathrm{~min}$. The reaction mixture was then purified by automated flash chromatography with $0-10 \%$ ethyl acetate in hexane. The product was collected as an oil after the solvent had been removed using a rotary evaporator.

2-Nitrobenzyl-3-phenylpropiolate (3a). o-Nitrobenzyl alcohol $(0.3 \mathrm{~g}, 2 \mathrm{mmol})$ was reacted with the acid as described in the general procedure to afford $1 \mathbf{d}$ as a yellowish oil $(0.2 \mathrm{~g}$, 72\%). NMR data were consistent with literature data: ${ }^{46}{ }^{1} \mathrm{H}$ NMR $\left(400 \mathrm{MHz}, \mathrm{CDCl}_{3}\right) \delta 8.17(\mathrm{dq}, J=8.2,0.9,0.9,0.9 \mathrm{~Hz}$, $1 \mathrm{H}), 7.70(\mathrm{~m}, 2 \mathrm{H}), 7.62(\mathrm{~m}, 2 \mathrm{H}), 7.49(\mathrm{~m}, 2 \mathrm{H}), 7.40(\mathrm{~m}, 2 \mathrm{H})$, $5.70(\mathrm{~s}, 2 \mathrm{H}) ;{ }^{13} \mathrm{C}$ NMR $\left(101 \mathrm{MHz}, \mathrm{CDCl}_{3}\right) \delta 153.16,147.16$, 133.80, 132.93, 131.23, 130.74, 128.83, 128.45, 125.04, 119.12, $87.42,79.89,63.95 ; \nu_{\max }$ (neat) 2215, 1707, 1524.

1-(2-Nitrophenylethyl-3-phenylpropiolate) (3b). 2b (0.32 g, $2 \mathrm{mmol}$ ) was reacted with the acid as described in the general procedure to afford 1e as a yellow oil $(0.4 \mathrm{~g}, 70 \%):{ }^{1} \mathrm{H}$ NMR $\left(400 \mathrm{MHz}, \mathrm{CDCl}_{3}\right) \delta 8.00(\mathrm{ddt}, J=8.2,1.2,0.5,0.5 \mathrm{~Hz}, 1 \mathrm{H})$, 7.76 (ddd, $J=8.0,1.5,0.6 \mathrm{~Hz}, 1 \mathrm{H}), 7.68$ (dddt, $J=7.9,7.3,1.2$, 0.5, $0.5 \mathrm{~Hz}, 1 \mathrm{H}), 7.59(\mathrm{~m}, 2 \mathrm{H}), 7.46(\mathrm{~m}, 2 \mathrm{H}), 7.38(\mathrm{~m}, 2 \mathrm{H})$, $6.51(\mathrm{~m}, 1 \mathrm{H}), 1.74(\mathrm{dd}, J=6.5,0.5 \mathrm{~Hz}, 3 \mathrm{H}) ;{ }^{13} \mathrm{C} \mathrm{NMR}(101$
$\left.\mathrm{MHz}, \mathrm{CDCl}_{3}\right) \delta 152.83,147.48,137.30,133.84,133.02,130.78$ $128.59,128.57,127.25,124.58,119.38,86.95,80.37,69.92$, 21.99; $\nu_{\max }$ (neat) 2210, 1704, 1523.

1-(2-Nitrophenyl)allyl-3-phenylpropiolate (3c). 2c (0.36 g, $2 \mathrm{mmol}$ ) was reacted with the acid as described in the general procedure to afford $3 \mathrm{c}$ as a yellow oil $(0.41 \mathrm{~g}, 66 \%):{ }^{1} \mathrm{H}$ NMR $\left(400 \mathrm{MHz}, \mathrm{CDCl}_{3}\right) \delta 8.01(\mathrm{ddt}, J=8.1,1.0,0.5,0.5 \mathrm{~Hz}, 1 \mathrm{H})$, $7.71(\mathrm{~m}, 2 \mathrm{H}), 7.60(\mathrm{~m}, 2 \mathrm{H}), 7.48(\mathrm{~m}, 2 \mathrm{H}), 7.39(\mathrm{~m}, 2 \mathrm{H}), 7.01$ $(\mathrm{dq}, J=5.2,0.9,0.9,0.7 \mathrm{~Hz}, 1 \mathrm{H}), 6.12$ (dddd, $J=17.3,10.5$, 5.7, $0.6 \mathrm{~Hz}, 1 \mathrm{H}), 5.41(\mathrm{~m}, 2 \mathrm{H}) ;{ }^{13} \mathrm{C} \mathrm{NMR}\left(101 \mathrm{MHz}, \mathrm{CDCl}_{3}\right)$ $\delta$ 152.36, 133.78, 133.66, 133.50, 132.91, 130.69, 128.81, $128.44,128.30,124.57,119.19,118.66,87.21,80.03,72.51 ; \nu_{\max }$ (neat) 2210, 1705, 1523.

1-(2-Nitrophenyl)but-3-en-1-yl-3-phenylpropiolate (3d). $2 \mathrm{~d}(0.13 \mathrm{~g}, 0.6 \mathrm{mmol})$ was reacted with the acid as described in the general procedure to afford $1 \mathrm{~g}$ as a yellow oil $(0.11 \mathrm{~g}$, 51\%): ${ }^{1} \mathrm{H}$ NMR (400 MHz, $\left.\mathrm{CDCl}_{3}\right) \delta 8.02(\mathrm{dd}, J=8.2,1.3 \mathrm{~Hz}$, $1 \mathrm{H}), 7.72(\mathrm{dd}, J=7.9,1.6 \mathrm{~Hz}, 1 \mathrm{H}), 7.67(\mathrm{ddd}, J=7.6,7.1,1.3$ $\mathrm{Hz}, 1 \mathrm{H}), 7.60$ (m, 2H), 7.46 (m, 2H), 7.39 (m, 2H), 6.53 (dd, J = 8.1, $4.2 \mathrm{~Hz}, 1 \mathrm{H}), 5.91$ (ddt, $J=17.2,10.2,7.0,7.0 \mathrm{~Hz}, 1 \mathrm{H})$, $5.16(\mathrm{~m}, 2 \mathrm{H}), 2.77(\mathrm{~m}, 2 \mathrm{H}) ;{ }^{13} \mathrm{C} \mathrm{NMR}\left(101 \mathrm{MHz}, \mathrm{CDCl}_{3}\right) \delta$ 152.92, 147.56, 135.72, 133.68, 133.04, 132.42, 130.81, 128.70, $128.57,127.72,124.73,119.36,118.92,87.19,80.27,72.52$, 40.15; $\nu_{\max }$ (neat) 2211, 1706, 1524.

(2-Nitrophenyl)(phenyl)methyl-3-phenylpropiolate (3e). $2 \mathrm{e}(0.15 \mathrm{~g}, 0.6 \mathrm{mmol})$ was reacted with the acid as described in the general procedure to afford $1 \mathrm{~h}$ as a yellow thick oil $(0.53$ g, 70\%): ${ }^{1} \mathrm{H}$ NMR (400 MHz, $\left.\mathrm{CDCl}_{3}\right) \delta 8.03(\mathrm{dd}, J=8.2,1.3$ $\mathrm{Hz}, 1 \mathrm{H}), 7.83(\mathrm{dd}, J=8.0,1.4 \mathrm{~Hz}, 1 \mathrm{H}), 7.71(\mathrm{~m}, 2 \mathrm{H}), 7.60(\mathrm{~m}$, 2H), $7.47(\mathrm{~m}, 4 \mathrm{H}), 7.38(\mathrm{~m}, 5 \mathrm{H}) ;{ }^{13} \mathrm{C}$ NMR (101 MHz, $\left.\mathrm{CDCl}_{3}\right) \delta 152.43,147.68,137.12,134.38,133.40,132.83$, $130.67,128.80,128.52,128.44,128.42,128.38,127.79,124.81$, 119.06, 87.35, 80.03, 73.78; $\nu_{\max }$ (neat) 2214, 1707, 1525.

General Procedure for the One-Pot CuAAC Reaction. Three milliliters of a $1 \mathrm{mM}$ solution of the esters in dichloromethane was injected through a microchannel reactor chip (Syrris, $62.5 \mu \mathrm{L}$ ) while being irradiated at $254 \mathrm{~nm}$ using a hand-held UV lamp (UVP; UVGL-25 Compact UV Lamp, 4 $\mathrm{W}, 254 / 365)$. The photoproduct was collected in a vial containing the click reagents [ $\mathrm{CuI}(3.8 \mathrm{mg}, 0.02$ equiv), DIPEA ( $5.2 \mathrm{mg}, 0.04$ equiv), and HOAC ( $2.4 \mathrm{mg}, 0.04$ equiv)]. The vial was heated to $60{ }^{\circ} \mathrm{C}$ until the amount of solvent was reduced by half. Then, azido anisole $(0.1 \mathrm{~mL})$ was added and the mixture stirred until it was dry $(15 \mathrm{~min})$. The crude product was re-dissolved in $\mathrm{CDCl}_{3}$ and passed through a short pipet plug containing anhydrous $\mathrm{MgSO}_{4}$ into an NMR tube. Then methyl-3,5-dinitrobenzoate $(30 \mu \mathrm{L})$ was added as an internal standard to determine the yield by quantitative ${ }^{1} \mathrm{H}$ NMR (32 scans, $10 \mathrm{~s}$ ds, $45^{\circ}$ pulse angle). ${ }^{47}$

\section{ASSOCIATED CONTENT}

\section{S Supporting Information}

The Supporting Information is available free of charge on the ACS Publications website at DOI: 10.1021/acs.bioconjchem.7b00812.

Photolysis experiment and quantum yield measurement, UV-visible absorption spectra, FTIR spectra, thermogravimetric spectra, and ${ }^{1} \mathrm{H}$ and ${ }^{13} \mathrm{C}$ spectra (PDF)

\section{AUTHOR INFORMATION}

\section{Corresponding Author}

*E-mail: mkasper@chalmers.se. 


\section{ORCID}

Kasper Moth-Poulsen: 0000-0003-4018-4927

\section{Notes}

The authors declare no competing financial interest.

\section{ACKNOWLEDGMENTS}

The authors are grateful to the European Research Council (ERC-StG \#337221, SIMONE) for funding. Dr. P. Jarvoll, Dr. T. Gschneidtner, and Dr. M. Jevric are kindly acknowledged for fruitful discussions.

\section{ABBREVIATIONS}

PPGs, photocleavable protected groups; NB, o-nitrobenzyl; $\varepsilon$, molar extinction coefficient; $\lambda$, wavelength; LC-MS, liquid chromatography-mass spectrometry; NMR, nuclear magnetic resonance; $\mathrm{CuAAC}, \mathrm{Cu}(\mathrm{I})$-catalyzed azide-alkyne cycloaddition

\section{REFERENCES}

(1) Wuts, P. G. M., and Greene, T. W. (2007) Greene's protective groups in organic synthesis, 4th ed., Wiley and Sons, Inc., Hoboken, NJ. (2) Klan, P., Solomek, T., Bochet, C. G., Blanc, A., Givens, R., Rubina, M., Popik, V., Kostikov, A., and Wirz, J. (2013) Photoremovable protecting groups in chemistry and biology: reaction mechanisms and efficacy. Chem. Rev. 113, 119-91.

(3) Bochet, C. G. (2001) Photolabile protecting groups and linkers. J. Chem. Soc., Perkin Trans. 1, 125-142.

(4) Wang, P. (2013) Photolabile Protecting Groups: Structure and Reactivity. Asian J. Org. Chem. 2, 452-464.

(5) Blanc, A., and Bochet, C. G. (2002) Wavelength-Controlled Orthogonal Photolysis of Protecting Groups. J. Org. Chem. 67, 55675577.

(6) Holmes, C. P. (1997) Model Studies for New o-Nitrobenyzl Photolabile Linkers: Substituent Effects on the Rates of Photochemical Cleavage. J. Org. Chem. 62, 2370-2380.

(7) Nicolaou, K. C., Hummel, C. W., Pitsinos, E. N., Nakada, M., Smith, A. L., Shibayama, K., and Saimoto, H. (1992) Total Synthesis of Calicheamicin Gamma-1(I). J. Am. Chem. Soc. 114, 10082-10084.

(8) Zhao, H., Sterner, E. S., Coughlin, E. B., and Theato, P. (2012) oNitrobenzyl Alcohol Derivatives: Opportunities in Polymer and Materials Sceince. Macromolecules 45, 1723-1736.

(9) San Miguel, V., Bochet, C. G., and del Campo, A. (2011) Wavelength-Selective Caged Surfaces: How many Functional Levels Are Possible? J. Am. Chem. Soc. 133, 5380-5388.

(10) Alonso, J. M., Reichel, A., Piehler, J., and del Campo, A. (2008) Photopatterned surfaces for site-specific and functional immobilization of proteins. Langmuir 24, 448-457.

(11) Stegmaier, P., Alonso, J. M., and Campo, A. D. (2008) Photoresponsive surfaces with two independent wavelength-selective functional levels. Langmuir 24, 11872-11879.

(12) Pelliccioli, A. P., and Wirz, J. (2002) Photoremovable protecting groups: reaction mechanisms and applications. Photochem. Photobiol. Sci. 1, 441-458.

(13) Moth-Poulsen, K., Kofod-Hansen, V., Kamounah, F. S., Hatzakis, N. S., Stamou, D., Schaumburg, K., and Christensen, J. B. (2010) Optically Induced Linking of Protein and Nanoparticles to Gold Surfaces. Bioconjugate Chem. 21, 1056-1061.

(14) Givens, R. S., Rubina, M., and Wirz, J. (2012) Applications of phydroxyphenacyl (pHP) and Coumarin-4-yl methyl Photoremovable Protecting Groups. Photochem. Photobiol. Sci. 11, 472-488.

(15) Barltrop, J. A., Plant, P. J., and Schofield, P. (1966) Photosensitive Protective Groups. Chem. Commun., 822-823.

(16) Kaplan, J. H., Forbush, B., III, and Hoffman, J. F. (1978) Rapid Photolytic Release of Adenosine 5'-Triphosphate from a Protected Analog - Utilization by the Na-K pump of Human Red Blood Cell Ghosts. Biochemistry 17, 1929-1935.
(17) Siemsen, P., Livingston, R. C., and Diederich, F. (2000) Acetylenic Coupling: A Powerful Tool in Molecular Construction. Angew. Chem., Int. Ed. 39, 2632-2657.

(18) Chinchilla, R, and Najera, C. (2007) The Sonogashira reaction: a booming methodology in synthetic organic chemistry. Chem. Rev. 107, 874-922.

(19) Kolb, H., Finn, M., and Sharpless, K. (2001) Click Chemistry: Diverse Chemical Function from a Few Good Reactions. Angew. Chem., Int. Ed. 40, 2004-2021.

(20) Meldal, M., and Tornøe, C. W. (2008) Cu-Catalyzed AzideAlkyne Cycloaddition. Chem. Rev. 108, 2952-3015.

(21) Johansson, J. R., Beke-Somfai, T., Said Stålsmeden, A., and Kann, N. (2016) Ruthenium-Catalyzed Azide Alkyne Cycloaddition Reaction: Scope, Mechanism, and Applications. Chem. Rev. 116, 14726-14768.

(22) Singh, M. S., Chowdhury, S., and Koley, S. (2016) Advances of Azide-Alkyne Cycloaddition-Click Chemistry over the Recent Decade. Tetrahedron 72, 5257-5283.

(23) Ekkebus, R., van Kasteren, S. I., Kulathu, Y., Scholten, A., Berlin, I., Geurink, P. P., de Jong, A., Goerdayal, S., Neefjes, J., Heck, A. J. R., Komander, D., and Ovaa, H. (2013) On Terminal Alkynes That Can React with Active-site Cysteine Nucleophiles in Proteases. J. Am. Chem. Soc. 135, 2867-2870.

(24) Tour, J. M. (1996) Conjugated Macromolecules of Precise Length and Constitution. Organic Synthesis for the Construction of Nanoarchitectures. Chem. Rev. 96, 537-554.

(25) Eastmond, R., Johnson, T. R., and Walton, D. R. M. (1972) Silylation as a Protective Method for Terminal Alkuynes in Oxidative Couplings: A General Synthesis of Polyenes. Tetrahedron 28, 46014616.

(26) Kolarovic, A., Schnürch, M., and Mihovilovic, M. D. (2011) Tandem Catalysis: From Alkynoic Acids and Aryl Iodides to 1,2,3Triazoles in One Pot. J. Org. Chem. 76, 2613-2618.

(27) Gschneidtner, T. A., and Moth-Poulsen, K. (2013) A Photolabile Protection Strategy for Terminal Alkynes. Tetrahedron Lett. 54, 5426-5429.

(28) Kitani, S., Sugawara, K., Tsutsumi, K., Morimoto, T., and Kakiuchi, K. (2008) Synthesis and Characterization of Thiochromone S,S-dioxides as New Photolabile Protecting Groups. Chem. Commun., 2103-2105.

(29) Ma, C., Zhang, Y., Zhang, H., Li, J., Nishiyama, Y., Tanimoto, H., Morimoto, T., and Kakiuchi, K. (2017) Synthesis and Photochemistry of a New Photolabile Protecting Group for Propargylic Alcohols. Synlett 28, 560-564.

(30) Ponpandian, T., and Muthusubramanian, S. (2012) Copper catalysed domino decarboxylative cross coupling-cyclisation reactions: synthesis of 2-arylindoles. Tetrahedron Lett. 53, 4248-4252.

(31) Neises, B., and Steglich, W. (1978) Simple Method for the Esterification of Carboxylic Acids. Angew. Chem., Int. Ed. Engl. 17, $522-524$.

(32) Ding, L. N., and Fang, W. H. (2010) Exploring Photoinduced Decarboxylation Mechanism of $o$-Acetylphenylacetic Acid from the Combined CASSCF and DFT Studies. J. Org. Chem. 75, 1630-1636.

(33) Suzuki, A. Z., Watanabe, T., Kawamoto, M., Nishiyama, K., Yamashita, H., Ishii, M., Iwamura, M., and Furuta, T. (2003) Coumarin-4-ylmethoxycarbonyls as Phototriggers for Alcohols and Phenols. Org. Lett. 5, 4867-4870.

(34) Knowles, J. P., Elliott, L. D., and Booker-Milburn, K. I. (2012) Flow photochemistry: Old light through new windows. Beilstein J. Org. Chem. 8, 2025-2052.

(35) Gilmore, K., and Seeberger, P. H. (2014) Continuous Flow Photochemistry. Chem. Rec. 14, 410-418.

(36) Plutschack, M. B., Pieber, B., Gilmore, K., and Seeberger, P. H. (2017) The Hitchhiker's Guide to Flow Chemistry parallel. Chem. Rev. 117, 11796-11893.

(37) Barth, A., Corrie, J. E. T., Gradwell, M. J., Maeda, Y., Mäntele, W., Meier, T., and Trentham, D. R. (1997) Time-Resolved Infrared Spectroscopy of Intermdediates and Products from Photolysis of 1-(2- 
Nitrophenyl)ethyl Phophates: Reaction of the 2-Nitroacetophenone Byproduct with Thiols. J. Am. Chem. Soc. 119, 4149-4159.

(38) Even though the acid photoproduct was not observed by NMR, evidence of its presence was obtained from infrared spectra recorded for $3 \mathrm{~d}$ using a low-power $310 \mathrm{~nm}$ lamp. The $310 \mathrm{~nm}$ lamp was used to minimize decarboxylation (see Figure S3).

(39) Adam, W., and Krebs, O. (2003) The Nitroso-ene Reaction: a Regioselective and Stereoselective Allylic Nitrogen Functionalization of Mechanistic Delight and Synthetic Potential. Chem. Rev. 103, 41314146.

(40) Orski, S. V., Sheppard, G. R., Arumugam, S., Arnold, R. M., Popik, V. V., and Locklin, J. (2012) Rate Determination of Azide Click Reactions onto Alkyne Polymer Brush Scaffolds: A Comparison of Conventional and Catalyst-Free Cycloadditions for Tunable Surface Modification. Langmuir 28, 14693-14702.

(41) Park, K., Heo, Y., and Lee, S. (2013) Metal-Free Decarboxylative Three-Component Coupling Reaction for the Synthesis of Propargylamines. Org. Lett. 15, 3322-3325.

(42) Su, M., Wang, J., and Tang, X. (2012) Photocaging strategy for functionalisation of oligonucleotides and its applications for oligonucleotide labelling and cyclisation. Chem. - Eur. J. 18, 96289637.

(43) Watanabe, S., Sato, M., Sakamoto, S., Yamaguchi, K., and Iwamura, M. (2000) New Dendritic Caged Compounds: Synthesis, Mass Spectrometric Characterization, and Photochemical Properties of Dendrimers with a-Carboxy-2-nitrobenzyl Caged Compounds at Their Periphery. J. Am. Chem. Soc. 122, 12588-12589.

(44) Matarlo, J. S., Evans, C. E., Sharma, I., Lavaud, L. J., Ngo, S. C., Shek, R., Rajashankar, K. R., French, J. B., Tan, D. S., and Tonge, P. J. (2015) Mechanism of MenE Inhibition by Acyl-Adenylate Analogues and Discovery of Novel Antibacterial Agents. Biochemistry 54, 65146524.

(45) Serafinowski, P. J., and Garland, P. B. (2003) Novel Photoacid Generators for Oligonucleotide Synthesis. J. Am. Chem. Soc. 125, 962965.

(46) Zhang, X., Zhang, W. Z., Shi, L. L., Zhu, C., Jiang, J. L., and Lu, X. B. (2012) Ligand-free $\mathrm{Ag}(\mathrm{I})$-catalyzed carboxylative coupling of terminal alkynes, chloride compounds, and CO2. Tetrahedron 68, 9085-9089.

(47) Shao, C. W., Wang, X. Y., Zhang, Q., Luo, S., Zhao, J. C., and Hu, Y. F. (2011) Acid-Base Jointly Promoted Copper(I)-Catalyzed Azide-Alkyne Cycloaddition. J. Org. Chem. 76, 6832-6836. 